\title{
The Rise of the Spirit of National Interest and the Existence of World Trade Organization Agreement: A Case Study of Indonesia
}

\author{
I Gusti Ngurah Parikesit Widiatedja* and I Gusti Ngurah Wairocana** \\ DOI: https://doi.org/10.22304/pjih.v4n2.a6
}

\begin{abstract}
There has been an anxiety over the rise of the spirit of national interest on the existence of World Trade Organization. This spirit that has been reflected from domestic trade policy, to some extent, has undermined trade negotiation process under the WTO as shown by the failure of the Doha Round to conclude significant trade deals. Countries also started concluding bilateral and regional trade agreements instead of the WTO. This article aimed to analyze whether the rise of the spirit of national interest has threaten the existence of the WTO agreements, putting Indonesia as a case study. This article is a normative research, analyzing the dynamics development of the national interest under the WTO, especially Indonesia, and how the judicial body has responded the rise of this spirit in its decisions. This article argues that the spirit of national interest will not threaten the existence of WTO as this spirit has existed from the early establishment of the General Agreement on Tariffs and Trade in 1947 to the latest WTO negotiation. Moreover, the existence of the WTO judicial body will secure the existence of the WTO, especially because it has successfully controlled the overwhelming spirit of national interest of its members through its decisions.
\end{abstract}

Keywords: case study, Indonesia, international agreement, the spirit of national interest, WTO.

\section{Kebangkitan Semangat Kepentingan Nasional dan Eksistensi Persetujuan World Trade Organization: Studi Kasus Indonesia}

\begin{abstract}
Abstrak
Telah timbul suatu kekhawatiran atas bangkitnya semangat kepentingan nasional terhadap eksistensi persetujuan WTO. Semangat ini yang tercermin dari kebijakan perdagangan domestik telah menghambat proses negosiasi perdagangan di bawah WTO sebagaimana ditunjukkan oleh kegagalan Putaran Doha dalam menyetujui kesepakatan perdagangan. Negara-negara juga mulai menyetujui kesepakatan perdagangan yang lebih bersifat bilateral dan regional. Artikel ini bertujuan untuk menganalisis apakah bangkitnya semangat kepentingan nasional telah mengancam eksistensi kesepakatan WTO, dengan menjadikan Indonesia sebagai studi kasus. Artikel ini adalah penelitian normatif, menganalisis perkembangan dinamika kepentingan nasional di bawah WTO, khususnya

PADJADJARAN Jurnal IImu Hukum Volume 4 Nomor 2 Tahun 2017 [ISSN 2460-1543] [e-ISSN 2442-9325]

* Lecturer at Faculty of Law Udayana University, Bali, Jl. Pulau Bali No. 1 Denpasar, ngurahparikesit@gmail.com, S.H., M.Hum. (Universitas Brawijaya), LL.M. (University of Washington), Ph.D Candidate (University of Melbourne).

** Professor of Law Udayana University Bali, Dean of Faculty of Law Udayana University (2008-2016), Jl. Pulau Bali No. 1 Denpasar, wairocanangurah@yahoo.co.id, S.H (Universitas Udayana), M.H., Dr. (Universitas Airlangga).
\end{abstract}


Indonesia, dan bagaimana badan judisial merespon bangkitnya semangat ini dalam keputusannya. Artikel ini berpendapat bahwa semangat kepentingan nasional tidak akan mengancam keberadaan WTO karena semangat ini telah ada sejak awal berdirinya GATT di 1947 sampai negosiasi WTO terakhir. Melalui keputusan-keputusan yang telah dihasilkan, keberadaan badan penyelesaian sengketa dalam WTO akan menjamin eksistensi WTO, terutama karena telah berhasil mengendalikan semangat kepentingan nasional dari anggota WTO.

Kata kunci: studi kasus, Indonesia, perjanjian internasional, semangat kepentingan nasional, WTO.

\section{A. Background}

The World Trade Organization (WTO) has existed since the last two decades. It has triggered the increase of international trade that subsequently lead to other significant benefits, such as providing more jobs in the short term, ${ }^{1}$ resulting 'substantive productivity gains', 2 and supporting the Sustainable Development Goals (SDGs) especially in order to alleviate poverty and hunger. ${ }^{3}$ WTO is important to reach world peace and stability. When governments concluded agreements, it was not only to reach economic prosperity but also security. ${ }^{4}$ Moreover, WTO has provided more rules-oriented dispute settlement process and promised a fair solution, putting all members in the equal position. ${ }^{5}$

Indonesia has been a member of the General Agreement on Tariffs and Trade (GATT) since 24 February 1950 and the WTO since 1 January $1995 .{ }^{6}$ Indonesia was involved in groups that promoted particular trade issues during the WTO negotiations. Almost in every negotiation, Indonesia committed to reduce its tariffs on trade. For example, in 2012, the Government issued Indonesian Custom Tariff Book that has resulted in a 10 percent reduction in the total number of MFN applied tariff lines. ${ }^{7}$

1 The Organization for Economic Cooperation and Development (OECD), "The Impact of Trade Liberalisation on Jobs and Growth: Technical Note", OECD Trade Policy Papers No. 107, 2011, p. 34.

2 Przemyslaw Kowalski, Max BügeKowalski, P. and M. Büge, "Assessing the Trade-Related Sources of Productivity Growth in Emerging Economies", OECD Trade Policy Papers No. 158, 2013, p. 44.

3 World Trade Organization (WTO), "World Trade Report 2014 Trade and Development: Recent Trends and The Role of the WTO", https://www.wto.org/english/res_e/booksp e/world trade report14 e.pdf, downloaded on 17 June 2017.

$4 \quad$ Hailay Gebretinsae Beyene, "Does International Trade Reduce Political Disputes?", Foreign Trade Review, Vol. 50, 2015, p. 114.

5 Joost Pauwelyn, "How to Win a WTO Dispute Based on Non-WTO Law? Questions of Jurisdiction and Merits", Journal of World Trade, Vol. 37, No. 6, 2003, p. 997.

6 WTO, "Indonesia and the WTO", https://www.wto.org/english/thewto e/countries e/indonesia e.htm downloaded on 21 June 2017.

7 WTO, "Trade Policy Review Indonesia", WTO Doc WT/TPR/S/278 (Report by the Secretariat), 6 March 2013, pp. 8-9. https://www.wto.org/english/tratop_e/tpr_e/s278_e.pdf, accessed on 25 July 2017. 
Since the last decade, the spirit of national interest may threaten the existence of WTO, looking at its failure to conclude significant trade deals. Specifically, the Doha Development Agenda (DDA) was declared 'dead'8 due to the harsh disagreement between developed countries and developing countries on issues relating to trade remedies and agriculture. ${ }^{9}$ Besides, there was also considerable debate against and between the EU and the USA relating to their agricultural subsidies for domestic industries. ${ }^{10}$ This failure became one of the reasons why WTO member states seem to prefer concluding bilateral and regional trade agreements.

The spirit of national interest has been reflected from domestic trade policy. This policy can take different forms, including measures favoring domestic companies, the increase of tariff barriers, monopoly actions, and anti-immigration policies. ${ }^{11}$ For instance, some members of the EU increased trade barriers to cross-border mergers and acquisitions because of the fear of losing national pride and jobs in consequence of merger measures. ${ }^{12}$ In a recent case, the Trump administration employs anti-dumping measures to unilaterally condemn any countries or companies whose products are damaging domestic producers. ${ }^{13}$ Indonesia itself still employed several non-tariff barriers (NTBs), such as import licenses and export restrictions despite it has successfully reduced its tariffs. ${ }^{14}$

Under the dispute settlement system under the WTO, some members have brought the case as opposed to other members' measures in relation to the protection of national interest. On 25 January 2017, the United States (US) brought a case before the Dispute Settlement Body (DSB) over China's measure on providing discriminatory support only for domestic agricultural producers. ${ }^{15}$ Two days later (27 January 2017), Canada requested a consultation under the DSB, complaining China's subsidies to domestic producers of primary aluminum. ${ }^{16}$ Indonesia is also involving in the DSB process. On 29 April 2016, Brazil requested a consultation,

$8 \quad$ Ibid, p. 27.

9 BBC News, "World Trade Talks End in Collapse”, 29 July 2008,

http://news.bbc.co.uk/2/hi/business/7531099.stm, accessed on 25 March 2017.

10 Ibid.

11 Nouriel Roubini, "Economic Insecurity and the Rise of Nationalism", The Guardian, 2 June 2014, https://www.theguardian.com/business/economics-blog/2014/jun/02/economic-insecurity-nationalismon-the-rise-globalisation-nouriel-roubini, accessed on 4 May 2017.

12 Raymond J. Ahearn, "Europe: Rising Economic Nationalism?", CRS Report for Congress, 6 July 2006, http://research.policyarchive.org/4378.pdf, downloaded on 18 June 2017.

13 World Policy, "Trump and Trade Bilateralism", 11 January 2017, http://www.worldpolicy.org/blog/2017/01/12/trump-and-trade-bilateralism, accessed on 1 July 2017.

14 Margit Molnar and Molly Lesher, "Indonesia" in OECD, Globalisation and Emerging Economies: Brazil, Russia, India, Indonesia, China, and South Africa, Paris: OECD, 2008, p. 334.

15 WTO, "China - Domestic Support for Agricultural Producers: Constitution of the Panel Established at the Request of the United States", WTO Doc WT/DS511/9, 26 June 2017, p. 1.

16 WTO, "China - Subsidies to Producers of Primary Aluminium: Request to Join Consultations Communication from Canada", WTO Doc WT/DS519/3, 31 January 2017, p. 1. 
claiming Indonesia has conducted illegal measure in relation to the importation of Bovine Meat. ${ }^{17}$ Meanwhile, on 15 July 2016, Indonesia requested a consultation, arguing that the US's imposition of anti-dumping and countervailing measures on certain coated paper products from Indonesia has violated with, among other things, the Agreement on Subsidies and Countervailing Measures (SCM) and Antidumping Agreement. ${ }^{18}$

This article argues that the spirit of national interest will not threaten the existence of WTO as this spirit has been exist from the early establishment of the General Agreement on Tariffs and Trade in 1947 to the latest WTO negotiation. Moreover, the existence of dispute settlement system will secure the existence of the WTO, especially because it has successfully controlled the overwhelming spirit of national interest of its members through its decisions.

This article starts by explaining the theory of comparative advantage, analyzing whether it has contributed to the common prosperity through international trade. This article then turns to describe how the dynamic development of the WTO has always been colored with the spirit of national interest. The explanation of the dispute settlement mechanism under the WTO shows how this system, to some extent, is still effective to distinguish the national interest and the political elite's interest of its members. Next, this article explains the dynamic participation of Indonesia in the WTO, showing how the spirit of national interest has existed since the old order. Finally, this article explains how the judicial body under the WTO has responded Indonesia's measures that were imposed to protect its national interest.

\section{B. Theoretical Framework}

\section{The Theory of Comparative Advantage behind the Establishment of the World} Trade Organization

The theory of comparative advantage remains relevant for modern trade practices. ${ }^{19}$ This theory explains the reliance of trade agreements on trade liberalization as a means of reaching broader policy objectives. ${ }^{20}$ The preamble of the WTO agreement identifies the reduction in barriers to trade as a means of achieving the goals of raising 'standards of living' and ensuring 'full employment' ${ }^{21}$

17 WTO, "Indonesia - Measures Concerning the Importation of Bovine Meat: Acceptance by Indonesia of the Requests to Join Consultations", WTO Doc WT/DS506/7, 29 April 2016, p. 1.

18 WTO, "United States - Anti-dumping and Countervailing Measures on Certain Coated Paper from Indonesia: Communication from the Panel", WTO Doc WT/DS491/5, 15 July 2016, p. 1.

19 Przemyslaw Kowalski, "Comparative Advantage and Trade Performance”, OECD Trade Policy Papers No. 121, 2011, p. 6

20 Ibid.

21 The Preamble of Marrakesh Agreement Establishing the World Trade Organization 1995 (The WTO Agreement 1995). 
In the Wealth of Nations, Adam Smith canvassed how international trade provides benefits by stating that: "If a foreign country can supply us with a commodity cheaper than we ourselves can make it, better buy it of them with some part of the produce of our own industry, employed in a way in which we have some advantage...".22

David Ricardo then described the theory of 'comparative advantage' in his book On the Principles of Political Economy and Taxation in 1817. ${ }^{23}$ Illustrating world economy only consist England and Portugal with only two goods, cloth and wine, were produced, he then stated that

"England may be so circumstanced, that to produce the cloth may require labour of 100 men for one year, and if she attempted to make wine, it might require the labour of 120 men for the same time. England would therefore find it her interest to import wine, and to purchase it by the exportation of cloth. To produce the wine in Portugal might require only the labour of 80 men for one year, and to produce the cloth in the same country might require the labour of 90 men for the same time. It would therefore be advantageous for her to export wine in exchange for cloth." 24

Bearing in mind this theory, Heckscher and Ohlin elaborated what constituted comparative advantage. They revealed that the relative endowments of the factors of production, including land, labor, and capital, determined countries' comparative advantage. ${ }^{25}$ Countries exported products that utilized their plentiful and inexpensive factors of production as their 'comparative advantage,' and imported products that utilized their rarer and more expensive factors. ${ }^{26}$ For example, Indonesia (in which labor and land are plentiful but capital is lacking) has a comparative advantage in producing coffee that require significant labor and land but little capital. According to the theory, Indonesia should therefore produce and export coffee while importing cars that require significant capital.

The theory comparative advantage, however, to some extent, conflicted with the theory of 'Justice as Fairness'. The theory of comparative advantage has neglected the fact that countries have uneven level of development so that free

22 Adam Smith, An Inquiry into the Nature and Causes of the Wealth of Nations, Chicago: University of Chicago Press, 1976, p. 478.

23 David Ricardo, On the Principles of Political Economy and Taxation, Cambridge: Cambridge University Press, 1951, p. 135.

24 Ibid.

25 Eli Heckscher, The Effect of Foreign Trade on the Distribution of Income, Sweden: Ekonomisk Tidskrift, 1919, p. 497 in Wei-Bin Zhang, International Trade Theory: Capital, Knowledge, Economic Structure, Money, and Prices over Time, New York: Springer, 2008, p. 4.

26 Mark Blaug, The Methodology of Economics, or, How Economists Explain, Cambridge: Cambridge University Press, 1992, p. 190. 
trade should be interpreted as fair trade. Inspiring social contract theory, John Rawls explained the conception of justice that should not only benefit the most advantaged parties, but also the least advantaged parties/groups in society. ${ }^{27}$ Rawls put emphasis on how a fairly distributed procedure took place in society. ${ }^{28}$ Through the principle of Fair Equality of Opportunity and the Difference Principle, Rawls argued that a community cannot organize dissimilarities to exploit the share of the least advantaged whereas not permitting access to certain positions. ${ }^{29}$

International leading scholars then pointed out how trade liberalization has not benefited yet the least advantaged parties. Muhammad Yunus, a Nobel Peace Prize winner, suggested that trade liberalization led to income inequality, pointing out that "ninety-four percent of the world income goes to 40 percent of the population while sixty percent of people live on only 6 percent of world income". ${ }^{30}$ Stiglitz warned that fast-moving trade liberalization without any "safety nets, with insufficient reciprocity and assistance on the part of developed countries, can contribute to an increase in poverty". ${ }^{31}$ Likewise, Krugman and Obstfeld explained that free trade can only work "if all other markets are working properly". ${ }^{32}$ If they are not, governmental intervention is required to mitigate the effects of market failures. ${ }^{33}$

\section{Recent Studies Explaining the Relationship between the National Interest and the Existence of the World Trade Organization}

Some studies explained how the spirit of national interest is linked to the existence of the WTO. Regan (2006) stated that there always are two possibilities of the role of WTO as multilateral trade agreement whether it restricts deliberate exploitation of market power or it restricts the spirit of national interest in the forms of protectionism. ${ }^{34}$ A study by Naoi (2009) examined that WTO members used WTO

27 Vernon Van Dyke, "Justice as Fairness: For Groups?", The American Political Science Review, Vol. 69, 1975, p. 607; See also Linda Sugin, "Theories of Distributive Justice and Limitations on Taxation: What Rawls Demands From Tax Systems", Fordham Law Review, Vol. 72, 2004, p. 1992.

28 Emmy Latifah, "Eksistensi Prinsip-prinsip Keadilan dalam Sistem Hukum Perdagangan Internasional", Padjajaran Jurnal Ilmu Hukum (Journal of Law), Vol. 2, No. 1, 2015, p. 67.

29 John Rawls, "Justice as Fairness: Political not Metaphysical," Philosophy and Public Affairs, Vol. 14, 1985, p. 223.

30 M hammad Yunus, "Nobel Lecture", (Oslo, 10 December 2006 ) http://nobelprize.org/nobel_prizes/peace/laureates/2006/yunus-lecture-en.html.

31 Joseph Stiglitz, "Addressing Developing Country Priorities and Needs in the Millennium Round", in Roger B Porter and Pierre Sauve (eds), Seattle, the WTO and the Future of the Multilateral Trading System, Harvard: Harvard University Press, 2000, pp. 53-55.

32 Paul Krugman and Maurice Obstfeld, International Economic: Theory and Policy, $7^{\text {th }}$ ed, Pearson, 2005, pp. 21417 in Andrew T Guzman and Joost HB Pauwelyn, International Trade Law, $2^{\text {nd }} \mathrm{Ed}$, South Holland: Wolters Kluwer, 2012, p. 21.

33 Ibid.

34 Donald H. Regan, "What Are Trade Agreements for? - Two Conflicting Stories Told by Economists, with a Lesson for Lawyers", Journal of International Economic Law, Vol. 9, No. 4, 2006, p. 951. 
instead of bilateral or unilateral agreements to impose protective measures to protect local industries, employing WTO legal instruments, such as voluntary export restraints and subsidy. ${ }^{35}$ Chang-fa Lo (2013) then explained how the spirit of national interest has been reflected when members take advantage from the vague concept of 'disguised restriction', 'arbitrary or unjustifiable discrimination' under the WTO by imposing protective trade measures. ${ }^{36}$ Similarly, Cottier (2015) stated that protectionism and local content requirements have become the most popular policy instruments to protect national interest under trade agreements. ${ }^{37}$

There have been studies showing the practice of WTO members to protect their national interest. Becker (2007) pointed out how the US and the EU have maintained their subsidies program for domestic producers and employed export cartel exemptions. ${ }^{38}$ Wu (2011) revealed that although China joined WTO in 2001, China has applied many protective and discriminatory trade measures. ${ }^{39}$ Takeuchi (2013) even argued that this practice was not different than the period when China was negotiating for accession to the WTO. ${ }^{40}$ Facchini (2010) then denoted how Latin American governments imposed import restrictions to control goods from particular countries, such as China and India. ${ }^{41}$

Although abovementioned studies have explained the relationship between national interest and the existence of the WTO, none of them specifically investigated that the national interest's spirit has been exist since the establishment of the GATT in 1947 and related to the existence of the WTO judicial body. Equally, some studies have put the practice of national interest from WTO members, but it has not yet examined or covered Indonesia.

35 Megumi Naoi, "Shopping for Protection: The Politics of Choosing Trade Instruments in a Partially Legalized World", International Studies Quarterly, Vol. 53, 2009, p. 421.

36 Chang-fa Lo, "The Proper Interpretation of 'Disguised Restriction on International Trade' under the WTO: The Need to Look at the Protective Effect", Journal of International Dispute Settlement, Vol. 4, No. 1, 2013, p. 111.

37 Thomas Cottier, "The Common Law of International Trade and the Future of the World Trade Organization", Journal of International Economic Law, Vol. 18, 2015, p. 4.

38 Florian Becker, "The Case of Export Cartel Exemptions: Between Competition and Protectionism", Journal of Competition Law and Economics, Vol. 3, No. 1, 2007, p. 97.

39 Xiaohui Wu, "No Longer Outside, Not Yet Equal: Rethinking China's Membership in the World Trade Organization", Chinese Journal of International Law, Vol. 10, 2011, p. 227.

40 Hiroki Takeuchi, "Political Economy of Trade Protection: China in the 1990s", International Relations of the AsiaPacific, Vol. 13, No. 1, 2013, p. 2.

41 Giovanni Facchini, (et.al), "Substitutability and Protectionism: Latin America's Trade Policy and Imports from China and India", The World Bank Economic Review, Vol. 24, No. 3, 2010, p. 446. 


\section{The Dynamic Developments of the World Trade Organization and the Spirit of National Interest}

\section{Bretton Woods and the Establishment of the General Agreement on Tariffs and Trade 1947}

Having experienced the Second World War, countries realized the significance of international institutions in reducing the likelihood of another world war. ${ }^{42}$ The Geneva Conference in 1947 successfully issued a multilateral treaty that so called the GATT $1947 .{ }^{43}$ However, the Charter for the ITO was yet to be agreed. ${ }^{44}$ The Havana Charter of 1948 subsequently tried to embody the ITO to complement the Bretton Woods system.$^{45}$ The refusal of the US Congress to ratify this treaty then led to the failure of the ITO. ${ }^{46}$ This process reflected how the seed of national interest (USA Congress) had risen that subsequently colored every trade negotiations under the GATT and WTO.

The failure of ITO did not make an absence of international trade law because the GATT 1947 gradually became a legal framework. ${ }^{47}$ Due to the high spirit of national interest, the first four negotiations did not make any significant progress in reducing tariff on a multilateral ground. ${ }^{48}$ The Kennedy Round of the 1960s, then necessarily reduced an average tariff to be 35 percent among the participants ${ }^{49}$ By the 1980s, trade in agriculture and trade in services became major concerns of the GATT 1947 contracting parties. ${ }^{50}$ Due to the overwhelming spirit of national interest (protectionism), agricultural sectors declined to a tiny portion, damaging many agricultural leading exporters. ${ }^{51}$

\section{The Uruguay Round and the Establishment of the World Trade Organization}

The Uruguay Round at Punta del Este, Uruguay in 1986 was the last trade negotiation under the framework of GATT 1947 that eventually concluded in

42 John H Jackson, "The Evolution of the World Trading System - the Legal and Institutional Context", in Daniel Bethlehem (et.al) (eds), The Oxford Handbook of International Trade Law, Oxford: Oxford University Press, 2009, p. 34.

43 The General Agreement on Tariffs and Trade, opened for signature 30 October 1947, 55 UNTS 187, entered into force 1 January 1948 (GATT 1947).

44 Mitsuo Matsushita (et.al), The World Trade Organisation, Oxford: Oxford University Press, 2015, p. 2.

45 Mihir Chatterjee, "Re-Negotiating Trade and Labor Standards in a Post Hong Kong Scenario", Asian Journal of WTO \& International Health Law and Policy, Vol. 2, No. 2, 2007, p. 473.

46 John H Jackson, "The Evolution of the World Trading System - the Legal and Institutional Context", Op.cit., p. 34-35.

47 Mitsuo Matsushita (et.al), Op.cit., p. 3.

48 lbid.

49 Gilbert R Winham, "The Evolution of the World Trading System - the Economic and Policy Context" in Daniel Bethlehem (et.al), The Oxford Handbook of International Trade Law, Op.cit., p. 15.

50 Gilbert R Winham, "The Evolution of the World Trading System - the Economic and Policy Context", Op.cit., p.18.

51 lbid. 
Marrakesh, Morocco, in April $1994 .^{52}$ The outcome of the Uruguay Round was commendable as it considerably expanded the scope and content of trade rules, governing the international trading system. ${ }^{53}$ Firstly, the Uruguay Round successfully established the WTO as a new international organization on trade ${ }^{54}$ equipped by various treaty-based, institutional articles including 'Members' instead of 'Contracting Parties'. ${ }^{55}$ Moreover, the establishment of the dispute settlement system, ${ }^{56}$ comprising ad hoc Panels and a standing Appellate Body, provided more judicial than political character for resolving any disputes, especially because it has more enforceable sanctions and compliance mechanisms than GATT 1947. ${ }^{57}$

The appealing approach of the Uruguay Round was the implementation of 'single undertaking' system wherein all participants who intended to be members of the WTO were required to accept the WTO agreement and associated legal instruments, such as General Agreement on Trade in Services (GATS) and Annexes, Agreement on Trade-Related Aspects of Intellectual Property Rights (TRIPs). ${ }^{58}$ This approach seemed to curb the overwhelming spirit of national interest from its member states because they were not allowed to choose particular agreements under WTO that suited to them and disobey agreements that contradicted with their national interests.

\section{The Doha Development Agenda}

After Uruguay Round, as the highest-level body of the WTO, Ministerial Conference held a meeting no less often than every two years. ${ }^{59}$ In Doha (2001), members started the Doha Round that so-called the DDA, reflecting one of the main objectives to promote issues relating to trade and development. ${ }^{60}$ Following the interest of developing countries, members intended to strengthen Special and Differential Treatment (SDT) in order to make it right on target. ${ }^{61}$ Specifically, members agreed to strengthen the 'enabling clause', allowing developed countries

52 Kenneth W. Abbot, "GATT as a Public Institution: The Uruguay Round and Beyond", Brook Journal of International Law, Vol. 18, 1992, p. 43.

53 Ibid.

54 Article l of the WTO Agreement 1995.

55 Matthias Herdegen, Principles of International Economic Law, Oxford: Oxford University Press, 2013, p. 175.

56 Annex 2 of the WTO Agreement 1995.

57 Matthias Herdegen, Loc.cit.

58 Article Il of the WTO Agreement 1995. See also Rafael Leal-Arcas, "Proliferation of Regional Trade Agreements: Complementing or Supplanting Multilateralism?", Chicago Journal of International Law, Vol. 11, No. 2, 2011, p. 597.

59 Sungjoon Cho, "The Demise of Development in the Doha Round Negotiations", Texas International Law Journal, Vol. 31, 2010, p. 573.

60 WTO, “Doha Round”, https://www.wto.org/english/tratop_e/dda_e/dda_e.htm, accessed on 18 March 2017.

61 WTO, "Special and Differential Treatment Provisions", https://www.wto.org/english/tratop_e/devel_e/dev_special_differential_provisions e.htm, accessed on 19 March 2017. 
to provide more favorable treatment and non-reciprocal differential treatment to developing countries. ${ }^{62}$

After long and winding negotiation process, DDA failed to conclude significant outcome, ${ }^{63}$ wherein Pascal Lamy, the Director-General of the WTO eventually declared in 2011 that the DDA was 'dead'. ${ }^{64}$ The main caused was the disagreement between developed countries (The USA, EU, and Japan) and developing countries (Brazil, China, India, and South Africa) on issues relating to trade remedies, agriculture, NTBs, and services. ${ }^{65}$ There was also substantial debate against and between the EU and the USA relating to their agricultural subsidies program. ${ }^{66}$

The failure of the WTO to achieve significant agreement would change its future. Major trading parties, such as the USA and the EU, have initiated some Preferential Trade Agreements (PTAs) both regionally and bilaterally as alternative forum to pursue trade liberalization and trade integration instead of the WTO. ${ }^{67}$ Equally important, the WTO would likely function to administer, to monitor, and to enforce existing trade agreements rather than a forum to yield new trade commitments. ${ }^{68}$

\section{National Interest and the World Trade Organization Judicial Body's Decision} The existence of Dispute Settlement Body (DSB) and Appellate Body (AB) of WTO is important to avoid members in employing the national interest concern as a means of justifying any violation of WTO agreement. Some experts have positively assessed the existing dispute settlement mechanism under the WTO. ${ }^{69}$ Unlike the GATT, the DSB has successfully introduced the precise time limits throughout the dispute settlement process. ${ }^{70}$ Lockhart and Voon presumed that appellate review in the WTO was working well, and experts remarked on the effectiveness and efficiency of appellate review that have contributed to the development of international trade law. ${ }^{71}$ Similarly, Guzman and Pauwelyn stated that the dispute settlement process was one of the most remarkable and successful aspects of the WTO. ${ }^{72}$

62 WTO, "The Doha implementation decision explained", https://www.wto.org/english/tratop_e/dda_e/ implem explained e.htm\#crosscutting, accessed on 19 March 2017.

63 Mitsuo Matsushita (et.al), The World Trade Organisation, Op.cit., p. 26.

64 Ibid, p. 27.

65 BBC Online, "World Trade Talks End in Collapse", Loc.cit.

66 Ibid.

67 Bernard Hoekman, “Plurilateral Agreements, Variable Geometry and the WTO" in Andreas Dür and Manfred Elsig (eds), Trade Cooperation: The Purpose, Design and Effects of Preferential Trade Agreements, Cambridge: Cambridge University Press, 2015, p. 535.

68 David A Gantz, Liberalising International Trade After Doha: Multilateral, Plurilateral, Regional, and Unilateral Initiatives, Cambridge: Cambridge University Press, 2013, p. 28.

69 Thomas A Zimmermann, "WTO Dispute Settlement at Ten: Evolution, Experiences \& Evaluation", The Swiss Review of International Economic Relations, Vol. 60, 2015, p. 53.

70 lbid.

71 John Lockhart and Tania Voon, "Review of the Appellate Review in the WTO Dispute Settlement System", Melbourne Journal of International Law, Vol. 6, 2005, p.476.

72 Andrew T Guzman and Joost HB Pauwelyn, Op.cit., p. 127. 
Some WTO judicial decisions have responded countries' measures that were imposed in relation to the promotion or protection of national interest. In Japan Leather II (US), Japan obliged importers of certain types of leather to receive import licenses and to obey with import quotas ${ }^{73}$ in order to protect the jobs of a certain minority group that is the Dowa People. ${ }^{74}$ Japan argued that the Dowa people were in the least advantaged situation both economically and socially because of unfair treatment based on a traditional class system. ${ }^{75}$ However, the panel invalidated Japan's measure as it had nullified or impaired benefits to other members, that is the US. ${ }^{76}$ Furthermore, in Japan - Alcoholic Beverages II, Japan imposed a lower tax on its traditional drinks compared to cognac, whisky, and white spirits, ${ }^{77}$ arguing that Japanese consumers culturally put shochu as different from those alcohol drinks and consumed it in different ways and settings. ${ }^{78}$ The Panel and Appellate Body then banned this measure because it fell within the meaning of 'internal taxation' so that it is contradicted with GATT Article III:2. ${ }^{79}$

In China - Audiovisual, China through its state-owned firms, screen publications, such as audio and video products including CDs, DVDs, books and newspapers. ${ }^{80}$ China reasoned that its measures was important as an preventive measure for reaffirming that those products did not have any pornography that inconsistent with cultural and societal value in China. ${ }^{81}$ Both the Panel and the Appellate Body decided this measure as illegal as it led to unfair conducts where China obliged the business of importing publications must be functioned by a exclusively State-owned firms, and omitted foreign firms from being permitted as publication importers so that this measure was not fall within the scope of general exception under GATT Article XX. ${ }^{82}$

In the future, the supremacy of the WTO judicial body's decision that controlled the overwhelming spirit of national interest will secure the existence of the WTO. Nevertheless, the primary role of the WTO will be more focused on supervising and upholding the existing trade agreements instead of concluding new trade deals.

73 WTO Panel Report, “Japanese Measures on Imports of Leather", L/5623 - 31S/94, 15/16 May 1984, (JapanLeather II Panel Report) [8].

74 Japan-Leather II Panel Report [15], [17]-[18].

75 Japan-Leather II Panel Report [21]-[22].

76 Japan-Leather II Panel Report [44].

77 WTO Appellate Body Report, "Japan - Taxes on Alcoholic Beverages", WT/DS8/AB/R, 1 November 1996 (Japan - Taxes on Alcoholic Beverages AB Report) [17].

78 WTO Panel Report, "Japan - Taxes on Alcoholic Beverages", WT/DS8/R, WT/DS10/R, WT/DS11/R, 1 November 1996 (Japan-Taxes on Alcoholic Beverages Panel Report) [4.54].

79 Japan-Taxes on Alcoholic Beverages AB Report [32].

80 WTO Panel Report, "China - Measures Affecting Trading Rights and Distribution Services for Certain Publications and Audiovisual Entertainment Products", WT/DS363/R, 12 August 2009. (China-Audiovisual Panel Report).

81 China-Audiovisual Panel Report [4.113-4.120].

82 China-Audiovisual Panel Report [4.113-4.120]. 


\section{The Dynamic Participation of Indonesia in the World Trade Organization and the Spirit of National Interest \\ 1. Old Order (1945-1966)}

In the early period of its participation, Indonesia made only a few trade commitments to other contracting parties. ${ }^{83}$ In the Kennedy Round (in 1964 and in 1967), through its statement of offers, Indonesia agreed to reduce import restrictions only on cloves and raw jute. ${ }^{84}$ According to supplementary offers in 1966, Indonesia then committed to reduce tariffs on the importation of raw materials, and semi-finished goods. ${ }^{85}$

The considerations of the statement of offers could explain why Indonesia made a few commitments during the Kennedy Round, especially related to the national interest at that time. The government of Indonesia stated that any trade commitments would be carried out, according to the economic and social development in Indonesia. ${ }^{86}$ The government indicated that the predominant factor restricting the importation of foreign goods was the limited availability of foreign exchange. ${ }^{87}$ Furthermore, the government had undertaken tariff reform to encourage and protect domestic industries. ${ }^{88}$ Further, Indonesia only agreed to the elimination or reduction of tariff and non-tariff barriers imposed upon export products of interest of Indonesia. ${ }^{89}$

The trade policy in Sukarno's administration could explain why Indonesia was not really active and made a few commitments in every trade negotiations. First, Indonesia was an exporter of primary products, such as oil and rubber so that market access was not Indonesia's interest. ${ }^{90} \mathrm{Next}$, the government still wanted to impose high tariff on import because trade taxes were the primary source of government income. ${ }^{91}$ A controversial policy (that was called "Benteng") was

83 HS Kartadjoemena, "Country Reports: Indonesia" in Patrick F J Macrory, Arthur E Appleton, and Michael G Plummer, The World Trade Organization: Legal, Economic and Political Analysis, Verlag Berlin Heidelberg: Springer, 2005, p. 140.

84 Republic of Indonesia Permanent Mission to GATT, "Statement of Offers as a Contribution to the Objective of the Trade Negotiation by the Government of Indonesia", 25 October 1965, https://www.wto.org/english/ docs e/gattbilaterals e/Kennedy 1964 1967/500147-0006/500147-0006.pdf, downloaded on 4 April 2017.

85 Republic of Indonesia Permanent Mission to GATT, "Indonesia-Reduction of Import Duties", L/2707, 30 November 1966, https://www.wto.org/english/docs e/gattbilaterals e/Kennedy 1964 1967/5001470006/500147-0006.pdf, downloaded on 4 April 2017.

86 Republic of Indonesia Permanent Mission to GATT, "Statement of Offers as a Contribution to the Objective of the Trade Negotiation by the Government of Indonesia: Additional Paragraph", 21 December 1965, https://www.wto.org/english/docs_e/gattbilaterals_e/Kennedy_1964_1967/500147-0006/5001470006.pdf, downloaded on 5 April 2017.

87 Ibid.

88 lbid.

89 Republic of Indonesia Permanent Mission to GATT, "Statement of Offers as a Contribution to the Objective of the Trade Negotiation by the Government of Indonesia", Loc.cit.

90 HS Kartadjoemena, "Country Reports: Indonesia", Op.cit., p. 39.

91 Douglas H Brooks and Guntur Sugiyarto, "Can the Poor Benefit from the Doha Agenda? the Case of Indonesia", 
enacted in April 1950 by giving a special treatment through soft and cheap credit to 'native' Indonesia while importing goods from overseas. ${ }^{92}$ The goal of this measure was to assist Indonesian amid the existence of the Dutch and the Chinese that dominated export and import process in Indonesia. ${ }^{93}$

\section{New Order (1966-1998)}

The first participation of Indonesia under this order was the Tokyo Round from 1973 to 1979. During this round, Indonesia played a limited role. The only publicly available document explaining the contribution of Indonesia in this Round was a list of tariff concessions as a result of the bilateral negotiation between Indonesia and the USA. ${ }^{94}$ In that document, Indonesia agreed to reduce tariffs on meat (frozen turkeys), fresh fruits (grapes), vegetable protein, and aircraft parts. ${ }^{95}$

Some reasons in relation to national interest could explain why Indonesia maintained its passive role during the Tokyo Round. In the first decade, similar to old order, new order seemed to apply protectionism. Because of its position as oil exporter, the rise of oil price provided massive gain so that the government considered the multilateral trade negotiation was not necessary for boosting Indonesian economy. ${ }^{96}$ Besides, the Government needed to restrict foreign trade through high tariffs and a multitude of NTBs in order to protect domestic industries. ${ }^{97}$ Suharto also increased import quotas, benefitting his cronies that commonly owned and dominated local companies in Indonesia. ${ }^{98}$

Indonesia was more active in the Uruguay Round due to the rise of manufactured and processed goods in Indonesia. ${ }^{99}$ Indonesia was involved in some groups that discussed some specific issues that suited to the Indonesia's interest at that time. First, Indonesia joined in a coalition that so-called 'The Cairns Group', ${ }^{100}$ consisting of 19 developed and developing agricultural exporting countries. ${ }^{101}$ This

\footnotetext{
ADB Working Paper No. 72, October 2005, p. 4-5.

92 Thee Kian Wie, "Policies for Private Sector Development in Indonesia", ADB Institute Discussion Paper No. 46, March 2006, p. 3.

$93 \quad$ Ibid

94 Republic of Indonesia Permanent Mission to GATT, "List of Indonesian Tariff Concessions", 31 October 1979, https://www.wto.org/english/docs_e/gattbilaterals_e/Tokyo_1973 79/500136-0001/500136-0001.pdf, downloaded on 6 April 2017.

95 Ibid.

96 HS Kartadjoemena, “Country Reports: Indonesia” Op.cit., p. 139.

97 K Bird and Christopher Manning, "Economic Reform, Labour, Markets and Poverty: The Indonesian Experience", in Kishor Sharma (ed), Trade Policy, Growth and Poverty in Asian Developing Countries, London: Routledge, 2003, p. 77.

98 Dan Marks, Zandenn and Jan Luiten Van, An Economic History of Indonesia, Oxford: Taylor and Francis, 2013, p. 171.

99 HS Kartadjoemena, "Country Reports: Indonesia", Op.cit., p. 143.

100 The Cairns Group, "Background on the Cairns Group and the WTO Doha Round", http://cairnsgroup.org/pages/wto_negotiations.aspx, accessed on 19 June 2017.

101 lbid.
} 
group had main goals to reform global agricultural trade by promoting free trade in agriculture and omitting the export subsidy that resulted agricultural crisis in the late 1980 s. ${ }^{102}$

\section{Reformation Order (1998-now)}

The first participation of Indonesia under this order was the Doha Round. In this round, Indonesia participated in groups that promoted particular trade issues that also benefitted Indonesia's interest. Indonesia continued its participation in the Cairns Group. ${ }^{103}$ This group kept promoting the significance of substantial reductions in trade-distorting domestic support and the removal of export subsidies. ${ }^{104}$ Indonesia also joined G-20, developing countries coalition to propose reforms of agriculture in developed countries with some flexibility for developing countries. ${ }^{105}$ Indonesia then chaired G-33 and became the host of G-33 meeting. ${ }^{106}$

As its participation under the WTO, Indonesia continued to reduce its tariff. While in 1995 the average tariff rate was 15.6 percent, the average tariff rate had decreased to 7.2 percent in 2003. ${ }^{107}$ In 2004, a tariff harmonization program was announced, providing a tariff reduction schedule between 2004 and 2010. ${ }^{108}$ According to this schedule, 94 percent of tariff lines would have rates at or below 10 percent by $2010 .^{109}$ In 2012, the Government issued Indonesian Custom Tariff Book (BTKI), following the World Custom Organization HS2012 nomenclature and the AHTN. ${ }^{110}$ This policy has resulted in a 10 percent reduction in the total number of MFN applied tariff lines. ${ }^{111}$ Specifically, the simple average MFN applied rate was 7.8 percent, including ad valorem equivalent duties. ${ }^{112}$ However, Indonesia still applied import licensing system to secure national interest in relation to health protection, ecological environment, security, and public moral. Other purposed of this measure is to reach socio-economic objectives, such as improving national competitiveness and avoiding smuggling actions. ${ }^{113}$

\footnotetext{
102 Ibid.

103 Ibid.

104 Ibid.

105 WTO, "Groups in the Negotiations", https://www.wto.org/english/tratop_e/dda_e/negotiating_groups_e.htm\#grp025, downloaded on 19 June 2017.

106 OECD, Globalisation and Emerging Economies: Brazil, ..., Loc.cit.

107 WTO, “Trade Policy Review Indonesia”, WTO Doc WT/TPR/G/184, 23 May 2007 (Report by Indonesia), p. 19.

108 Margit Molnar and Molly Lesher, "Indonesia”, Op.cit., p. 338.

109 Ibid.

110 WTO, "Trade Policy Review Indonesia", WTO Doc WT/TPR/S/278, 6 March 2013 (Report by the Secretariat), pp. 8-9.

111 Ibid.

112 Ibid.

113 WTO, "Replies to Questionnaire on Import Licensing Procedures of Indonesia, Notification under Article 7.3 of the Agreement on Import Licensing Procedures", WTO Doc G/LIC/N/3/IDN/8, 2 November 2015.
} 
Since the last six years, there have been some indications how the spirit of national interest has risen. Firstly, in 2011, a group of non-governmental organization (NGO) brought a complaint to the Constitutional Court of Indonesia, claiming that the Law Number 38 of 2008 on the Ratification of Charter of the Association of Southeast Asian Nations had contradicted to the constitution of Indonesia. The ratification would endanger the economic rights of Indonesian and it was suspected as the new colonialism and imperialism. The constitutional court, through the decision No. 33/PUU-IX/2011 finally refused the NGO's entire claim. ${ }^{114}$

In 2014, the government enacted Law Number 3 of 2014 on Industry (Law on Industry). The spirit of national interest is reflected in some articles. Article 31 mentions that, in order to improve value added to natural resources, the government will encourage domestic processing productions. ${ }^{115}$ In the same way, Article 32 states that the government may restrict the export of natural resources in order to enhance the value added of domestic industry. ${ }^{116}$ The government then enacted the Law Number 7 of 2014 on Trade. The controversial issue can be found in Article 85 by stating that, subject to approval of House of Representatives, the government may reconsider and cancel international trade agreements' approval based on the concern of national interest. ${ }^{117}$ The law, however, did not further elucidate what the meaning of cancellation, and what constitute a national interest. This law may contradict with the provision on the termination in the Vienna Convention on the Law of Treaties of $1969 .{ }^{118}$

\section{Indonesia's National Interest and the World Trade Organization Judicial Body's Decision}

Under the WTO, Indonesia has involved in some WTO cases both as a complainant and a respondent. Some important cases, especially related to national interest issue are hereby explained. In Indonesia - Certain Measures Affecting the Automobile Industry in 1996, The European Union (EU), Japan, and the USA brought a complaint to Indonesia over National Car Programs. ${ }^{119}$ They alleged that the exemption from customs duties and luxury taxes on imports of 'national vehicles' and components thereof, were in violation of Indonesia's obligations under Articles I and III of GATT 1994, and Article 2 of the Agreement on Trade-Related Investment

\footnotetext{
114 The Decision No. 33/PUU-IX/2011 of the Constitutional Court of Indonesia.

115 Article 31 of Law Number 3 Year 2014 on Industry (Law on Industry).

116 Article 32 of Law on Industry.

117 Article 85 of Law Number 7 Year 2014 on Trade (Law on Trade).

118 See Huala Adolf, "The Indonesian Trade Law of 2014: The Provision on the Annulment of International Trade Agreement", Journal of International Commercial Law and Technology, Vol. 10, No. 1, 2015, p. 36.

119 WTO Panel Report, "Indonesia - Certain Measures Affecting the Automobile Industry", WTO Doc WT/DS54/R, WT/DS55/R, WT/DS59/R, WT/DS64/R, Corr. 1, Corr. 2, Corr. 3, and Corr. 4, 23 July 1998, p. 2201.
} 
Measures (TRIMs). ${ }^{120}$ The Panel then ruled that Indonesia violated those agreements. ${ }^{121}$ The national car program was an example how Indonesia had employed national interest concern to violate the WTO agreement. However, this interest was not actually the national interest, but rather the political or family elite's interest by looking at the parties who were involved in this program. In particular, one of president's children was the leader of company that was granted a permit to import 'national car' from Korea without having an obligation to pay what has been said at that time as the compulsory 35 percent lavish tax on cars. ${ }^{122}$

In 2012, in US - Clove Cigarettes, defending its national interest, Indonesia brought a case, complaining the US's prohibition on clove cigarettes from Indonesia while allowing the production and sale of the local cigarettes. ${ }^{123}$ The appellate body then confirmed this complaint, arguing the prohibition was the violation of national treatment principle under Technical Barriers to Trade (TBT) agreement. ${ }^{124}$ In 2014, in Indonesia - Importation of Horticultural Products, Animals and Animal Products, Indonesia imposed import licensing requirement for horticultural products and animals and animal products in order to secure food safety and 'halal' requirements. ${ }^{125}$ New Zealand and the US brought a case, alleging that Indonesia conducted quantitative import restrictions that was illegal under the GATT 1994, and violated the Agreement on Agriculture. ${ }^{126}$ The panel then ruled that Indonesia's measures were illegal and must be promptly revoked. ${ }^{127}$ Nevertheless, on 17 February 2017, Indonesia decided to appeal to the Appellate Body and this case is still underway.

In the future, Indonesia can still employ domestic trade policy in order to protect its national interest. From old order to reformation order and in every trade negotiation forum, Indonesia has issued multifarious trade-restrictive measures for protecting Indonesia's interest. WTO has acknowledged the need of Indonesia as a developing country that should not be forced to comply with all WTO agreements. However, Indonesia should be more cautious for imposing measures and not to be overly restrictive or protective. It will prevent other WTO members to bring a case before the WTO judicial body.

\footnotetext{
120 Ibid.

121 Ibid.

122 Thomas Lindblad, "The Political Economy of Recovery in Indonesia", in Jolle Demmers (et.al), Good Governance in the Era of Global Neoliberalism, Oxford: Taylor and Francis, 2004, p. 219.

123 WTO Appellate Body Report, "United States - Measures Affecting the Production and Sale of Clove Cigarettes", WT/DS406/AB/R, adopted 24 April 2012, DSR 2012: XI, p. 5751.

124 Ibid.

125 WTO Panel Report, "Indonesia - Importation of Horticultural Products, Animals and Animal Products", WTO Doc WT/DS477/R, 22 December 2016, p. 28.

126 Ibid, p. 278

127 Ibid.
} 


\section{E. Conclusion}

There has been an anxiety over the rise of the spirit of national interest on the existence of WTO. This spirit that has been reflected from domestic trade policy, to some extent, has undermined trade negotiation process under the WTO as shown by the failure of the Doha Round to conclude significant trade deals. Countries also started concluding bilateral and regional trade agreements instead of the WTO. This article shows that there has been the spirit of national interest in the dynamic development of the WTO from the establishment of GATT 1947 to the latest trade negotiation rounds under the WTO. This spirit also colored the dynamic participation of Indonesia from old order to reformation order. This fact, therefore, will not threaten the existence of the WTO as it has experienced with this situation since the GATT 1947 was concluded. Moreover, the existence of the WTO judicial body will secure the existence of the WTO, especially because it has successfully controlled the overwhelming spirit of national interest of its members, including Indonesia through its decisions. In the future, the existence of the WTO will likely be more focused on controlling and enforcing the existing trade agreements rather than concluding new trade commitments due to the rise of bilateral and regional trade agreements.

\section{References}

\section{Books}

Bethlehem, Daniel, (et.al) (eds), The Oxford Handbook of International Trade Law, Oxford University Press, Oxford, 2009.

Blaug, Mark, The Methodology of Economics, or, How Economists Explain, Cambridge University Press, Cambridge, 1992.

Demmers, Jolle, (et.al), Good Governance in the Era of Global Neoliberalism, Taylor and Francis, Oxford, 2004.

Dür, Andreas and Manfred Elsig (eds), Trade Cooperation: The Purpose, Design and Effects of Preferential Trade Agreements, Cambridge University Press, Cambridge, 2015.

Gantz, David A, Liberalising International Trade After Doha: Multilateral, Plurilateral, Regional, and Unilateral Initiatives, Cambridge University Press, Cambridge, 2013.

Guzman, Andrew T and Joost HB Pauwelyn, International Trade Law, Wolters Kluwer, South Holland, 2012.

Herdegen, Matthias, Principles of International Economic Law, Oxford University Press, Oxford, 2013.

Macrory, Patrick F J, Arthur E Appleton, and Michael G Plummer, The World Trade Organization: Legal, Economic and Political Analysis, Springer, Verlag Berlin Heidelberg, 2005. 
Marks, Dan, Zandenn and Jan Luiten Van, An Economic History of Indonesia, Taylor and Francis, Oxford, 2013.

Matsushita, Mitsuo, (et.al), The World Trade Organisation, Oxford University Press, Oxford, 2015.

Porter, Roger B and Pierre Sauve (eds), Seattle, the WTO and the Future of the Multilateral Trading System, Harvard University Press, Cambridge, 2000.

Ricardo, David, On the Principles of Political Economy and Taxation, Cambridge University Press, Cambridge, 1951.

Sharma, Kishor (ed), Trade Policy, Growth and Poverty in Asian Developing Countries, Routledge, London, 2003.

Smith, Adam, An Inquiry into the Nature and Causes of the Wealth of Nations, University of Chicago Press, Chicago, 1976.

The Organization for Economic Cooperation and Development, Globalisation and Emerging Economies: Brazil, Russia, India, Indonesia, China, and South Africa, OECD, Paris, 2008.

Zhang, Wei-Bin, International Trade Theory: Capital, Knowledge, Economic Structure, Money and Prices over Time, Springer, New York, 2008.

\section{Other Documents}

Abbot, Kenneth W, "GATT as a Public Institution: The Uruguay Round and Beyond", Brook Journal of International Law, Vol. 18, 1992.

Ahearn, Raymond J., "Europe: Rising Economic Nationalism?", CRS Report for Congress, 6 July 2006, http://research.policyarchive.org/4378.pdf, downloaded on 18 June 2017.

BBC News, "World Trade Talks End in Collapse", 29 July 2008, http://news.bbc.co.uk/2/hi/business/7531099.stm, accessed on 25 March 2017.

Becker, Florian, "The Case of Export Cartel Exemptions: Between Competition and Protectionism", Journal of Competition Law and Economics, Vol. 3, No. 1, 2007.

Beyene, Hailay Gebretinsae, "Does International Trade Reduce Political Disputes?", Foreign Trade Review, Vol. 50, 2015.

Brooks, Douglas H and Guntur Sugiyarto, "Can the Poor Benefit from the Doha Agenda? the Case of Indonesia", ADB Working Paper No. 72, October 2005.

Chatterjee, Mihir, "Re-Negotiating Trade and Labor Standards in a Post Hong Kong Scenario", Asian Journal of WTO \& International Health Law and Policy, Vol. 2, No. 2, 2007.

Cho, Sungjoon, "The Demise of Development in the Doha Round Negotiations", Texas International Law Journal, Vol. 31, 2010. 
Cottier, Thomas, "The Common Law of International Trade and the Future of the World Trade Organization", Journal of International Economic Law, Vol. 18, 2015.

Dyke, Vernon Van, “Justice as Fairness: For Groups?", The American Political Science Review Vol. 69, 1975.

Emmy Latifah, "Eksistensi Prinsip-prinsip Keadilan dalam Sistem Hukum Perdagangan Internasional", Padjajaran Jurnal IImu Hukum (Journal of Law), Vol. 2, No. 1, 2015.

Facchini, Giovanni, (et.al), "Substitutability and Protectionism: Latin America's Trade Policy and Imports from China and India", The World Bank Economic Review, Vol. 24, No. 3, 2010.

Huala Adolf, "The Indonesian Trade Law of 2014: The Provision on the Annulment of International Trade Agreement", Journal of International Commercial Law and Technology, Vol. 10, No. 1, 2015.

Leal-Arcas, Rafael, "Proliferation of Regional Trade Agreements: Complementing or Supplanting Multilateralism?", Chicago Journal of International Law, Vol.. 11, No. 2, 2011.

Lo, Chang-fa, "The Proper Interpretation of 'Disguised Restriction on International Trade' under the WTO: The Need to Look at the Protective Effect", Journal of International Dispute Settlement, Vol. 4, No. 1, 2013.

Lockhart, John and Tania Voon, "Review of the Appellate Review in the WTO Dispute Settlement System", Melbourne Journal of International Law, Vol. 6, 2005.

Kowalski, Przemyslaw, "Comparative Advantage and Trade Performance", OECD Trade Policy Papers No. 121, 2011.

Kowalski, Przemyslaw, Max BügeKowalski, P. and M. Büge, "Assessing the TradeRelated Sources of Productivity Growth in Emerging Economies", OECD Trade Policy Papers No. 158, 2013.

Naoi, Megumi, "Shopping for Protection: The Politics of Choosing Trade Instruments in a Partially Legalized World", International Studies Quarterly, Vol. 53, 2009.

Pauwelyn, Joost, "How to Win a WTO Dispute Based on Non-WTO Law? Questions of Jurisdiction and Merits", Journal of World Trade, Vol. 37, No. 6, 2003.

Rawls, John, "Justice as Fairness: Political not Metaphysical," Philosophy and Public Affairs, Vol. 14, 1985.

Regan, Donald H, "What Are Trade Agreements for? - Two Conflicting Stories Told by Economists, with a Lesson for Lawyers", Journal of International Economic Law, Vol. 9, No.4, 2006.

Republic of Indonesia Permanent Mission to GATT, "Indonesia-Reduction of Import Duties", L/2707, 30 November 1966, 
https://www.wto.org/english/docs e/gattbilaterals e/Kennedy 1964 1967/ 5001470006/500147-0006.pdf, downloaded on 4 April 2017. "List of Indonesian Tariff

Concessions", 31 October 1979, https://www.wto.org/english/docs e/gattbilaterals e/Tokyo 1973 79/50013 60001/500136-0001.pdf, downloaded on 6 April 2017.

"Statement of Offers as a

Contribution to the Objective of the Trade Negotiation by the Government of Indonesia", 25 October 1965,

https://www.wto.org/english/docs_e/gattbilaterals_e/Kennedy_1964_1967/ 5001470006/500147-0006.pdf, downloaded on 4 April 2017. "Statement of Offers as a

Contribution to the Objective of the Trade Negotiation by the Government of Indonesia: Additional Paragraph", 21 December 1965,

https://www.wto.org/english/docs e/gattbilaterals e/Kennedy 1964_1967/ 5001470006/500147-0006.pdf, downloaded on 5 April 2017.

Roubini, Nouriel, "Economic Insecurity and the Rise of Nationalism", The Guardian, 2 June 2014, https://www.theguardian.com/business/economicsblog/2014/jun/02/economic-insecurity-nationalism-on-the-rise-globalisationnouriel-roubini, accessed on 4 May 2017.

Sugin, Linda "Theories of Distributive Justice and Limitations on Taxation: What Rawls Demands From Tax Systems", Fordham Law Review, Vol. 72, 2004.

Takeuchi, Hiroki, "Political Economy of Trade Protection: China in the 1990s", International Relations of the Asia-Pacific, Vol. 13, No.1, 2013.

The Cairns Group, "Bacground on the Cairns Group and the WTO Doha Round", http://cairnsgroup.org/Pages/wto negotiations.aspx, accessed on 19 June 2017.

The Organization for Economic Cooperation and Development, "The Impact of Trade Liberalisation on Jobs and Growth: Technical Note", OECD Trade Policy Papers No. 107, 2011.

Wie, Thee Kian, "Policies for Private Sector Development in Indonesia", $A D B$ Institute Discussion Paper No. 46, March 2006.

World Policy, "Trump and Trade Bilateralism", 11 January 2017, http://www.worldpolicy.org/blog/2017/01/12/trump-and-trade-bilateralism, accessed on 1 July 2017.

World Trade Organization, "China - Domestic Support for Agricultural Producers: Constitution of the Panel Established at the Request of the United States", WTO Doc WT/DS511/9, 26 June 2017. 
Request to Join Consultations Communication from Canada", WTO Doc WT/DS519/3, 31 January 2017. , "Doha Round", , accessed on 18 March 2017. "Groups in the Negotiations",

https://www.wto.org/english/tratop e/dda e/negotiating_groups e.htm\#gr p025, downloaded on 19 June 2017.

"Indonesia - Measures Concerning the Importation of Bovine Meat: Acceptance by Indonesia of the Requests to Join Consultations", WTO Doc WT/DS506/7, 29 April 2016. , "Indonesia and the WTO",

https://www.wto.org/english/thewto e/countries e/indonesia e.htm, downloaded on 21 June 2017.

, "Replies to Questionnaire on Import Licensing Procedures of Indonesia, Notification under Article 7.3 of the Agreement on Import Licensing Procedures", WTO Doc G/LIC/N/3/IDN/8, 2 November 2015.

, "Special and Differential Treatment Provisions", https://www.wto.org/english/tratop e/devel e/dev special differential_pro visions e.htm, accessed on 19 March 2017.

"The Doha implementation decision explained", https://www.wto.org/english/tratop e/dda_e/implem explained e.htm\#cro sscutting, accessed on 19 March 2017.

World Trade Organization, "United States - Anti-dumping and Countervailing Measures on Certain Coated Paper from Indonesia: Communication from the Panel", WTO Doc WT/DS491/5, 15 July 2016.

"World Trade Report 2014 Trade and Development:

Recent Trends and The Role of the WTO",

https://www.wto.org/english/res e/booksp e/world trade report14 e.pdf, downloaded on 21 January 2017.

Appellate Body Report, "Brazil - Measures Affecting

Desiccated Coconut", WTO Doc WT/DS22/AB/R, 20 March 1997.

Beverages", WT/DS8/AB/R, 1 November 1996. "Japan - Taxes on Alcoholic

"United States - Measures

Affecting the Production and Sale of Clove Cigarettes", WT/DS406/AB/R, adopted 24 April 2012, DSR 2012: XI.

Panel Report, "China - Measures Affecting Trading Rights

and Distribution Services for Certain Publications and Audiovisual Entertainment Products", WT/DS363/R, 12 August 2009. 
"Indonesia - Certain Measures Affecting the Automobile Industry", WTO Doc WT/DS54/R, WT/DS55/R, WT/DS59/R, WT/DS64/R, Corr. 1, Corr. 2, Corr. 3, and Corr. 4, 23 July 1998.

, "Indonesia - Importation of Horticultural Products, Animals and Animal Products", WTO Doc WT/DS477/R, 22 December 2016.

, “Japan - Taxes on Alcoholic Beverages", WT/DS8/R, WT/DS10/R, WT/DS11/R, 1 November $1996 .$.

Leather", L/5623-31S/94, 15/16 May 1984. "Japanese Measures on Imports of , "Trade Policy Review Indonesia", WTO Doc WT/TPR/G/184, 23 May 2007 (Report by Indonesia).

, "Trade Policy Review Indonesia", WTO Doc WT/TPR/S/278, 6 March 2013 (Report by the Secretariat), https://www.wto.org/english/tratop e/tpr e/s278 e.pdf, accessed on 25 July 2017.

Wu, Xiaohui, "No Longer Outside, Not Yet Equal: Rethinking China's Membership in the World Trade Organization", Chinese Journal of International Law, Vol. 10, 2011

Yunus, Muhammad, "Nobel Lecture", (Oslo, 10 December 2006) http://nobelprize.org/nobel_prizes/peace/laureates/2006/yunus-lectureen.html.

Zimmermann, Thomas A, "WTO Dispute Settlement at Ten: Evolution, Experiences \& Evaluation" The Swiss Review of International Economic Relations, Vol. 60, 2015.

\section{Legal Documents}

Law Number 3 Year 2014 on Industry.

Law Number 7 Year 2014 on Trade.

The General Agreement on Tariffs and Trade 1947.

Marrakesh Agreement Establishing the World Trade Organization 1995.

The Constitutional Court of Indonesia Decision No. 33/PUU-IX/2011. 